\title{
Does Human Soul Have an Owner?
}

\section{Patristic Anthropology and Wittgenstein on the Human Identity}

\author{
Basil Lourié \\ Leading Research Fellow, Institute of Philosophy and Law of the Siberian \\ Branch of the Russian Academy of Sciences, Novosibirsk, Russia \\ hieromonk@gmail.com
}

\begin{abstract}
In the mainstream anthropology of Byzantine patristics, the human "I" is twice inconsistent, being identical to but different from a "part of God" and, in the created world, being not a something while without being a nothing. The latter kind of inconsistency was described as well by Ludwig Wittgenstein in his peculiar doctrine of subjectivity.
\end{abstract}

\section{Keywords}

patristic anthropology - Gregory of Nazianzus - subject - free will - Wittgenstein

\author{
Das Ich, das Ich ist das tief Geheimnisvolle! \\ LUdWig WitTGenstein, Notebook, August 5, 1916 ${ }^{1}$
}

\footnotetext{
* This research was carried out with a financial support of the Russian Science Foundation, project 18-18-oo134, "The heritage of Byzantine Philosophy in twentieth and twenty-first century Russian and Western European philosophy".

1 “The I, the I is what is deeply mysterious!"; L. Wittgenstein, Notebooks 1914-1916. Ed. G.H. von Wright and G.E.M. Anscombe with an English translation by G.E.M. Anscombe. Oxford, 1961 [repr. New York, 1969], pp. 8o/8oe (txt/tr.).
} 
Until recently, the patristic scholars were limited themselves, in their logical metalanguage, to the logical traditions of antiquity, even though their own mind would have been often shaped with modern philosophies. Logic is, however, something connected to but different from philosophy we follow. It is much more formal thing than philosophy or even ontology alone and is closer to mathematics than to philosophy. This is why no philosophy could provide a new logical metalanguage useful for understanding the logical structures of patristic thought. However, the development of logic since the early twentieth century and especially since the 1970s was certainly fruitful for better understanding of the logic(s) of the Fathers providing necessary theories for constructing richer and much more powerful logical metalanguages.

The problem of human immortal individuality turned out to be one of the most logically difficult in the Middle Age, and a new logical metalanguage for an explication of the relevant patristic ideas would be certainly welcome. By a strange - or perhaps revealing - coincidence, a similar logical problem was faced by Ludwig Wittgenstein, whose intuitions were formulated ad hoc and without exploring the pertinent logics deeper (almost unknown in Wittgenstein's lifetime, 1889-1951). Nevertheless, despite a theological and ontological gap, Wittgenstein's ideas on metaphysical subject, misunderstood by the most of modern philosophers and rejected by others, even by his own disciples (who understood him well but have disagreed) approximately coincide, in their logical form, with the teaching of the Eastern Fathers on human individuality and self-identity. From a logical (not theological or ontological) point of view, both Byzantine Fathers and Wittgenstein mean the same and, therefore, would help each other to be understood by a modern reader.

\section{The Ultimate Object of Treatment}

The ascetic doctrines of the Church Fathers represent themselves as an art of healing. However, the object of this medical treatment, unlike that of the ordinary one, is not the body but the soul. ${ }^{2}$ It is tempting to compare this with the modern psychotherapy and psychiatry, and, indeed, there is a lot of overlapping at the practical level, to the extent that some modern theories of psychotherapy are looking for borrowings in the teaching of the Desert Fathers. ${ }^{3}$

2 Cf. J.-Cl. Larchet, Thérapeutique des maladies spirituelles : une introduction à la tradition ascétique de l'Église orthodoxe, Paris, 1997.

3 See esp. I. Graiver, Asceticism of the Mind: Forms of Attention and Self-Transformation in Late Antique Monasticism. (Studies and Texts, 213), Toronto, 2018. An earlier attempt by Gavin 
Nevertheless, there is a sharp difference as to the ultimate object of treatment. In Christian asceticism, this is, to use a phrase from a Church hymn, "the soul, an immortal thing." ${ }^{4}$ The secular medicine, on the contrary, does not deal with immortal substances.

Let us quote the classical definition of Gregory of Nazianzus from the homily where he elaborated the topic of priestly duties and spiritual care (Oratio 2, 16). It would be especially useful for us, because, a bit later in the same homily, Gregory will put a finger on the break in the apparent logical chain of such reasoning.

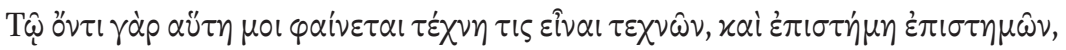

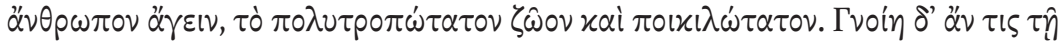

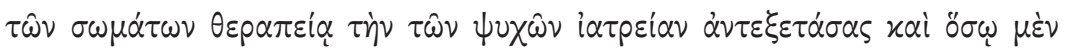

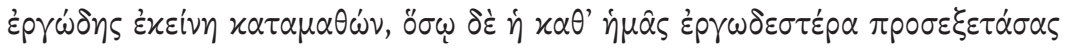

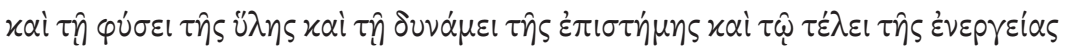
$\tau \iota \mu \iota \omega \tau \dot{\rho} \rho{ }^{5}$

For the guiding of man, the most variable and manifold of creatures, seems to me in very deed to be the art of arts and science of sciences. Any one may recognize this, by comparing the work of the physician of souls with the treatment of the body; and noticing that, laborious as the latter is, ours is more laborious, and of more consequence, from the nature of its subject matter, the power of its science, and the object of its exercise.

At first glance, it is not so important whether the object of treatment is by nature immortal or not, providing that the treatment is aimed at other functions than immortality itself. Indeed, in many cases, the quality of (im)mortality could be factored out. This is the reason why the secular therapy and ascetical teaching are - and always were - overlapping. However, the understanding of the ultimate object of therapy in asceticism is the most important not only for theology. It is vital for philosophical anthropology and even logic too, because it deals directly with the question what the human individuality is.

Flood, The Ascetic Self: Subjectivity, Memory, and Tradition, Cambridge, 2004 (ch. 6 "The asceticism of the desert," pp. 144-174), is hardly successful, because the author is not a specialist in either Christianity or psychology (the relevant chapter is rather superficial and contains some errors like "Optimo" instead of "Optina", p. 145; cf. his reference to Dostoevsky as an authority in the topic).

4 From the standard ("common") troparion to the holy monks:


to care instead for the soul, since it is an immortal thing").

5 J. Bernardi, Grégoire de Nazianze, Discours 1-3 (SC 247), Paris, 1978, pp. 110, 112. 
Indeed, according to Christian doctrines, the human individuality is something immortal. And, indeed, this is the ultimate object of ascetic treatment. However, the very notion of individuality escaped from the logical tenets of antique Greek logic.

According to Aristotle, the individuation was performed with the individual idiomata that distinguish this individuum within its nature, that is, from other individuals belonging to the same nature. In such logic, if there are no common idiomata (individualising features), there would be no identity. ${ }^{6}$ The Church Fathers have used this logic but have tried not to absolutize it. Already Gregory of Nazianzus in his polemics against Eunomius used an example of its breaking as a part of his argumentation for legitimacy of contradictions in theological doctrines (Oratio 29; De Filio, 9). His example is the so-called Paradox of Coming to Being:

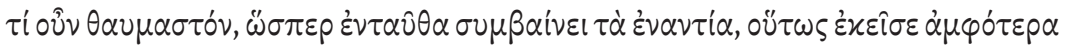

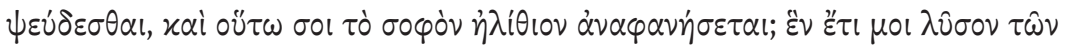

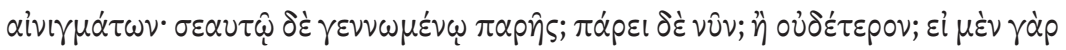

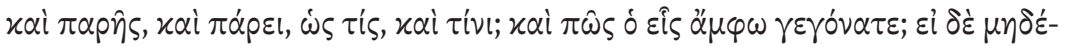

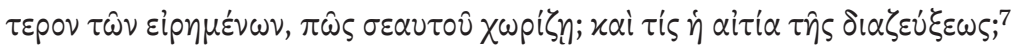

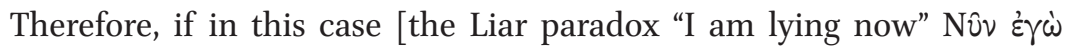
$\left.\psi \varepsilon v^{\delta} \delta \mu_{\alpha l}\right]$ the opposites coincide, then there is no need to wonder, why in the other case [the Paradox of Coming to Being] both opposites are false

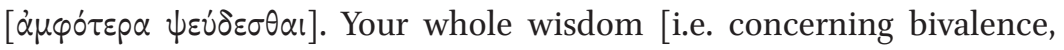
which Gregory wants to refute here] will be idiotic. Solve one more problem for me: is it you, who were there during the process of your coming to be you, and you, who are there now? Both alternatives are not the case, are they? Because if the one who was and is there, is in both cases yourself, then who and where is this? And how could you be two different things, since you are unique? But if nothing of what is said holds [i.e. if

6 For a modern account of Aristotelian individuation and its modern criticisms, see E.T. Olson, "Identity, Quantification, and Number," in: Contemporary Aristotelian Metaphysics, ed. T.E. Tahko, Cambridge, 2012, pp. 66-82. For the main problems of the Aristotelian understanding of individual, see esp. E.J. Lowe, The Four-Category Ontology: A Metaphysical Foundation for Natural Science, Oxford, 2006.

7 P. Gallay, Grégoire de Nazianze, Discours 27-37 (SC 250), Paris, 1978, pp. 194, 196. 
you are/were there in the one sense but not in the other], then how can you part with yourself? And what is the reason for tearing yourself apart?8 And what is the reason of disjoining?

This paradox is referred to by Gregory, in general, as an argument against the Aristotelian "law" (as it has been called later) of identity. Aristotle provided a verbose explication of this principle in Metaphysics IV $(\Gamma)$, 4, where the core is 1006 a 29-31:

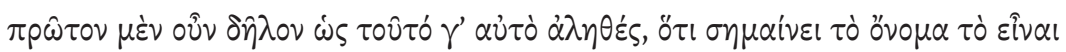

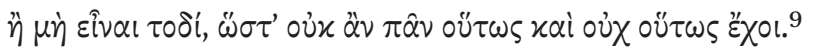

First then this at least is obviously true, that the word 'be' or 'not be' has a definite meaning, so that not everything will be so and so."10

The main Aristotle's idea is that anything that could be described in some particular way is always precisely the same thing that can be described in this way. This Aristotelian definition of identity through description was summarised, in the modern times, in the so-called Leibniz's principle that postulates identity of any two individuals whose all properties are identical. ${ }^{11}$

Now let us leave the anti-Aristotelian polemics and turn to the positive meaning implied in Gregory's use of the Paradox of Coming to Being. He interpreted this kind of non-identity of the identical(s) as "both opposites are false

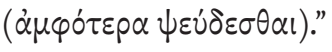

In logic, this corresponds to the contrary opposition (the upper part of the logical square, A-E). The classical logic would allow to an object $X$ to be either $A$ or non- $A$, but never not $A$ and not non- $A$ (contrary opposition) as well as never $A$ and non-A (subcontrary opposition). Gregory interpreted the Liar paradox as an example the subcontrary opposition (the person who says "I am lying now" is both lying and not lying), whereas the paradox of Coming to Being as a case of the contrary opposition (the person who changed was both not identical and not non-identical to him-/herself).

8 So far, translation by Stamatios Gerogiorgakis, "The Byzantine Liar," History and Philosophy of Logic, 30 (2009), pp. 313-33o, at pp. 316-317.

9 I. Bekker, ed. Aristotelis Opera, pars II. Ed. altera quam curavit O. Gigon. Berlin, 1960, p. 1006.

10 J. Barnes, ed. The Complete Works of Aristotle. The Revised Oxford Translation, vol. 2 (Bollingen series 71:2), Princeton, 1984, p. 1589 .

11 Cf. F. Chernoff, "Leibniz's Principle of the Identity of Indiscernibles," The Philosophical Quarterly, 31 (1981), pp. 126-138. 
The Paradox of Coming to Being, in its interpretation by Gregory (there are other interpretations of this paradox ${ }^{12}$ but we are interested only in that of Gregory), breaks the Aristotelian "law" of tertium non datur (excluded middle): the human could be, in the classical logic, either $A$ or non- $A$, but here she/he is both non- $A$ and not non- $A$ : both opposite suppositions are false.

The modern reader could easily recognise in this person, who is both non- $A$ and not non- $A$, the Schrödinger cat, who is both dead and not dead, because it is in the condition of quantum superposition. Indeed, the individuality of the quantum objects is described with contrary oppositions breaking the principle of excluded middle. This is why such objects are now called "non-individuals" (by Newton da Costa, Décio Krause and others) in the sense that they are not identical to themselves, thus breaking the "law" of identity, $A=A$. For them, $A \neq A$. According to a helpful comparison by Erwin Schrödinger himself (in his 1953 lecture), these objects are mutually indistinguishable as dollars on a bank account: they are countable, even though not individualisable. ${ }^{13}$

However, for the quantum objects, it is still an excuse for them being nonindividuals, because they, at least, belong to the microworld. The human being, however, is a macro-object - and still is, according to Gregory, a non-individual, even though this non-individuality is limited to the temporal dimension. The human being is countable - each human being is a unique object - but not identical to her- or himself.

The non-individuals are objects for which $A \neq A$. A classical non-individual object for patristic discourse is the body of resurrection. The oversimplification by Gregory of Nyssa, the so-called theory of sphragidation (implying the material identity between the dead and the resurrected bodies), never became obligatory, but its direct opposition, the various Origenist theories, especially that of John Philoponos, insisting on the absolute absence of material identity

12 For a modern discussion, see, e.g., that of Roderick M. Chisholm, Person and Object. A Metaphysical Study, La Salle, IL, 1976, pp. 89-113 (Ch. III: Identity through Time); idem, On Metaphysics, Minneapolis, MI, 1989, pp. 17-61 (Part II: Coming into Being, Persisting, and Passing Away). For a more formal approach, see D. Hyde, "Are the Sorites and Liar Paradox of Kind?" in: Paraconsistency: Logic and Applications, ed. K. Tanaka, F. Berto, E. Mares, F. Paoli. (Logic, Epistemology, and the Unity of Science, 26), Dordrecht, 2013, pp. 349-366.

On this logic, see esp. S. French, D. Krause, Identity in Physics, Oxford, 2006; N.C.A. da Costa, C. de Ronde, "Non-reflexive Logical Foundations for Quantum Physics," Foundations of Physics, 44 (2014), pp. 1369-1380; D. Krause, J.R.B. Arenhart, "Is Identity Really so Fundamental?" Foundations of Science, 24 (2019), pp. 51-71. 
were condemned. The identity of the material bodies after resurrection and their dead predecessors became the normative doctrine without, however, any explication of the criteria of identity. ${ }^{14}$ The western 1270 os scholastic discussions about either formal or numeral unity between the dead and the resurrected bodies repeated, without knowing this, the sixth-century Byzantine discussions. ${ }^{15}$

It is interesting that the Thomist position condemned shortly before the death of Thomas Aquinas - insisting on the uniquely formal unity between the two bodies and denying their numeral identity - repeated that of John Philoponos as I have reconstructed from Syriac fragments. However, Thomas, unlike Philoponos, implied an exclusion for the resurrected body of Christ considering the latter to be numerically identical to Christ's crucified body. This reservation did not save Aquinas's twenty theses from the condemnation in 1270 in Paris. The scholastic consensus eventually repeated the path of its sixth-century Byzantine predecessors: it insisted on the numerical identity between the two bodies, albeit without being able to explain what criteria of identity would have been applicable here.

However, in Gregory of Nazianzus's treatment of the paradox of Coming to Being, we see that not only human body but also the human person as a whole is a non-individual object in the sense of the modern quantum logic by da Costa and Krause.

For the sake of completeness of the logical background of Gregory, here I summarise my logical analysis of his doctrine and his disciple Evagrius's Trinitarian doctrine. The need to legitimise contradictions in logics arrived to Gregory of Nazianzus from the Triadology.

The situation with human beings that we have described above is mirroring the situation between the hypostases of the Holy Trinity, which deals with Gregory in more details. ${ }^{16}$ There, in the Trinity, the basic opposition is the subcontrary one, and the Aristotelian "law" broken in this case is that of non-contradiction: $A$ is both $A$ and non- $A$ (each of the three hypostases is both perfectly

14 See, for a detailed account, B. Lourié, "John Philoponus on the Bodily Resurrection," Scr, 9 (2013), pp. 91-100.

15 Cf. C.W. Bynum, The Resurrection of the Body in Western Christianity, 200-1336, New-YorkChichester, 1995, pp. 271-278.

16 Cf. B. Lourié, "What Means 'Tri-' in 'Trinity'? An Eastern Patristic Approach to the 'QuasiOrdinals," Journal of Applied Logic, 6 (2019), pp. 1093-1107. 
distinct and perfectly identical to any other). For such objects, it is always true that $A=A$ (they are individuals, each hypostasis is equal to itself), but, with the same token, $A=B$ (each hypostasis is also equal to any other hypostasis of the same nature). In the human nature, on the contrary, it is always true that $A \neq B$ (the human beings are different from each other), but, moreover, $A \neq A$ (the human beings are different from themselves as well).

Let us consider a kind of a logical square of the identity relation:

\begin{tabular}{|ll}
\hline A: Not Distinct & E: Not Identical \\
I: Identical & O: Distinct
\end{tabular}

A-E (contrary opposition): In classical logic, the conjunction of $\mathrm{A}$ and $\mathrm{E}$ is allowed: something could be not identical to but not distinct from something else (e.g., an amalgam of both), however, the conjunction of their negations is forbidden: something could not be not not distinct from and not not identical to something else. However, according to Gregory, man is both not not identical to himself and not not distinct from himself. The logic allowing such inconsistences is called paracomplete.

I-O (subcontrary opposition): In classical logic, the conjunction of I and $\mathrm{O}$ is forbidden: something could not be both identical to and distinct from something else, however, the conjunction of their negations is allowed: something could be not identical to nor distinct from something else (being, e.g., similar and barely distinguishable). However, the hypostases of the Trinity are both distinct from and identical to each other. The logic allowing such inconsistences is called paraconsistent.

We are now prepared to see that the human individuality turns out to be elusive in even more important respects.

The use of the paradox of Coming to Being by Gregory of Nazianzus would make us prepared to see that the principle of human individuality - which is also the ultimate object of spiritual therapy - cannot be grasped with any of its descriptions. Let us continue to read Gregory's Oratio 2 (ch. 17). Gregory continued $(\S 17)$ to describe the Christian art of healing the soul:

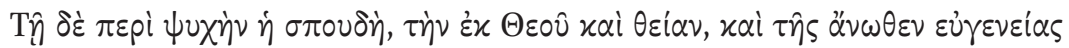

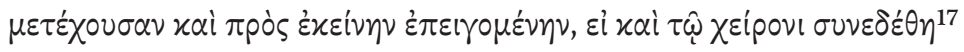


The other is concerned with the soul, which comes from God and is divine, and partakes of the heavenly nobility, and presses on to it, even if it be bound to an inferior nature.

Here and elsewhere, Gregory insists on the divine presence in the human soul. This teaching is specific to eastern patristics, at least, from Tatian ${ }^{18}$ and going back to late Jewish doctrines, especially Philonic. However, the presence of God in any human soul and without an intermediary was not the teaching of Philo, who supposed an intermediary. However, the similarity between Philo's doctrine of the image of God in man and the teaching of the Cappadocian Fathers and later patristics is rather striking, despite a great theological difference.

Thus, Philo wrote: 19

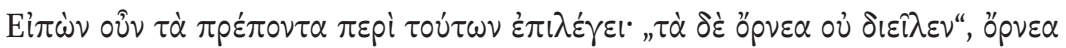

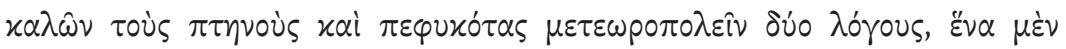

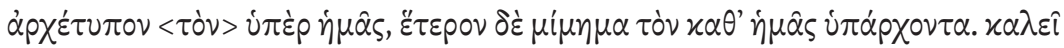

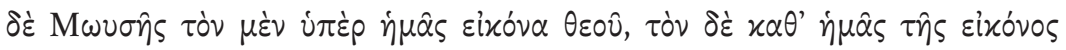

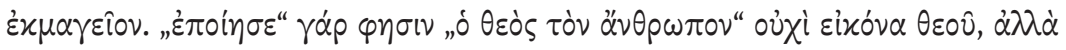

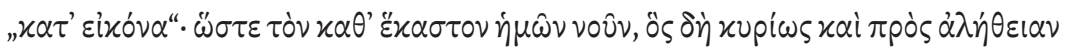

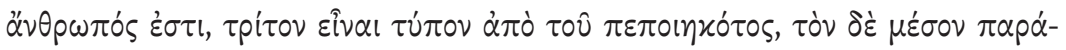

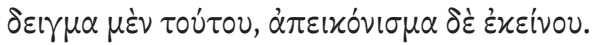

Therefore, after he has said what is becoming on this subject, he proceeds to add, But the birds he did not Divide (Gen 15:10); meaning, by the term birds, the two reasonings which are winged and inclined by nature to soar to the investigation of sublime subjects; one of them being the archetypal pattern and above us, and the other being the copy of the former and abiding among us. And Moses calls the one which is above us the image of God, and the one which abides among us as the impression of that image, For, says he, Godmade man, not an image, but after that Image (Gen 1:27). So that the mind which is in each of us, which is in reality and truth the man, is a third image proceeding from the Creator. But the intermediate one is a model of the one and a copy of the other.

18 Cf. his Oratio ad Graecos, 15.5 (on God's dwelling with the divine spirit in the human, which is the only meaning of being according to the image of God): M. Marcovich, Tatiani Oratio ad Graecos (PTS, 43), Berlin-New York, 1995, pp. 32-33. 
This system of correspondence between the archetype (God) and two images, after having been put into the Cappadocian framework, results in the mutual relations between the Father and the image of His hypostasis (Heb 1:3: $\chi \alpha \rho \alpha \varkappa \tau \eta े \rho$ $\tau \hat{\eta} \varsigma \dot{\tau} \pi \circ \sigma \tau \dot{\alpha} \sigma \varepsilon \omega \varsigma \alpha \dot{v} \tau \circ \hat{v})$, the Son.

The respective teaching of Gregory of Nazianzus has been developed by Maximus the Confessor, in the seventh century, into the doctrine of the noncreated divine logoi that are present in any human person and attract this person to the unique Logos, the Son of God (Ambigua, 7). Maximus elaborated on the passage of Gregory (Oratio 14.7), where the idea of a direct divine presence even in the fallen man is quite explicit: ${ }^{20}$

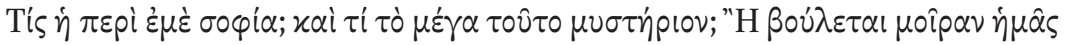

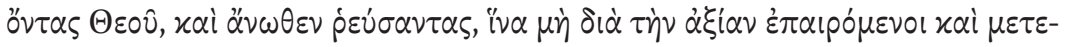

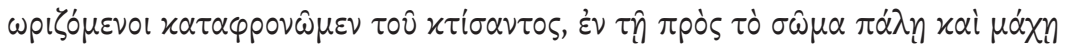

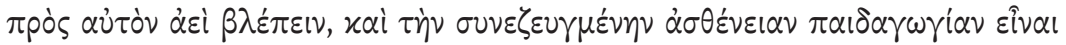
$\tau 0 \hat{\alpha} \dot{\xi} เ \omega \dot{\omega} \mu \alpha \tau \circ \varsigma$.

What is the wisdom that concerns me? And what is this great mystery? Or is it God's will that we, who are a portion of God that has flowed down from above, not become exalted and lifted up on account of this dignity, and so despise our Creator? Or is it not rather that, in our struggle and battle with the body, we should always look to Him, so that this very weakness that has been yoked to us might be an education concerning our dignity?

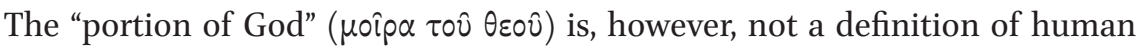
individuality. This is God but as far as he is acting within a man, in either accord or disaccord of the human will. ${ }^{21}$

$20 \quad P G$ 35, 865 C; tr. by Nicholas [now monk Maximos] Constas within his bilingual edition: Maximos the Confessor, On Difficulties in the Church Fathers. The Ambigua. Ed. and Translated by N. Constans. (Dumbarton Oaks Medieval Library), 2 vols. Cambridge, MA - London, 2014, vol. 1, p. 75; cf. the whole text of Ambiguum 7 at pp. 74/75-140/141 (txt/tr.). For the deification doctrine in general, see esp. J.-Cl. Larchet, La divinisation de l'homme selon saint Maxime le Confesseur. (Cogitatio fidei, 194), Paris, 1996.

$21 \quad$ For the notion of free will in Maximus (and its implied logic), see B. Lourié, "A Freedom beyond Conflict: The Logic of Internal Conflict and the Free Will in Maximus the Confessor," Scr, 14 (2018), pp. 63-74. This understanding, based especially in an often overlooked passage of the Opuscula theologica et polemica, 1, where Maximus comments on his own earlier explanation in the Ambigua, 7 , is somewhat different from that of Nikolaos Loudovikos (who, in my opinion, "psychologises" and, therefore, trivialises Maximus's thought): cf. esp. N. Loudovikos, "Being and Essence Revisited: Reciprocal Logoi and Ener- 
Where is the subject of the individual human which is considered without this divine component? We have to look for it in the human individual intellect

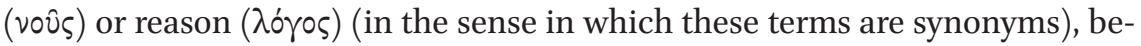
cause any capacities of the soul belong to the human being, in the same manner as the body with its capacities, but do not constitute the very identity of this being. Without these capacities, the human being would be handicapped but remains him- or herself.

In the anthropology where the centre of the human being is the image of God but considered as not the God himself, it would be easy to point out the subject of ascetic treatment: this is this image, whatever its relations to such immaterial "organs" as the intellect or the reason could be. Such anthropology has been widespread, while not in Byzantium, and, as it seems, has never been condemned. However, this was not the anthropology (or the anthropologies) of Gregory of Nazianzus, Maximus the Confessor, Dionysius the Areopagite, and such early authors as Tatian... In the other words, this was not the mainstream of Byzantine theological thinking.

Then, we need to find out the subject of ascetical treatment in the anthropology (anthropologies), where the central position in the human being is oc-

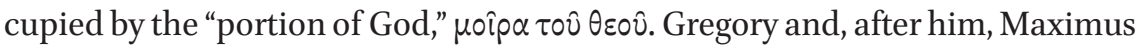
did not say that we have within us some "portion of God" but they said much more than this: "we are the portion of God." Therefore, this "portion of God" is, in some way, the principle of our identity. However, before the deification is accomplished, still we are not God. There is a contradiction here, which needs to be made explicit.

The principle of identification of the human being is "the portion of God," but the human being is not identical to "the portion of God." The ultimate object of healing of his soul from sins is not "the portion of God." This object could be approached from the two sides: from God - as his "portion" - and

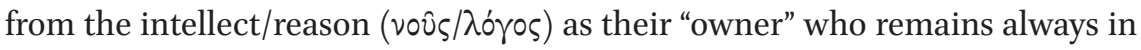
background. However, the subject, without being not identical with both, is

gies in Maximus the Confessor and Thomas Aquinas, and the Genesis of the Self-referring Subject," Revista Portuguesa de Filosofia, 72 (2016), pp. 117-146; cf. idem, "Consubstantial Selves: A discussion between Orthodox personalism, existential psychology, Heinz Kohut, and Jean-Luc Marion," in: Personhood in the Byzantine Christian Tradition: Early, Medieval, and Modern Perspectives, eds. A. Torrance, S. Paschalidis, London-New York, 2018, pp. 182196. Nevertheless, Loudovikos is certainly right looking forward for approaching Maximus's and Wittgenstein's thoughts in several respects; cf. N. Loudovikos, " $\Delta t-\varepsilon v v o \eta \mu \alpha \dot{\tau} \tau \omega \sigma \varsigma$ or Intermeaningfullness: Reading Wittgenstein through Gregory Palamas' and Thomas Aquinas' readings of Aristotle," in: Ludwig Wittgenstein between Analytic Philosophy and Apophatism, ed. S. Mitralexis, Cambridge, 2015, pp. 151-165; idem, Church in the Making:An Apophatic Ecclesiology of Consubstantiality, New York, 2015. 
not distinct from them either. The identification of the human subjectness with "the portion of God" prevents its identification with the intellect or the logos. However, this identification is not consistent because implies as well another subjectness - which is not identical, whereas not distinct from being "a portion of God."

To sum up, there are two kinds of inconsistences related to the human identity: identity with the other (divine) and non-identity with the self. ${ }^{22}$ Now, dealing with the problem of spiritual healing, we have to put aside the problem of identity with the divine and focus ourselves on the very elusiveness of the human self.

It is easy to see that the Patristic treatment of subjectivity described above goes in line with rather marginal trends in modern philosophy sometimes called, using Schleiermacher's term, "non-objectal (ungegenständlich) subjectivity," that is, a subjectivity which is irreducible to objectness. There must be, in my individuality, some "I" that could never been considered as an object, as a "He/ She/It."23 After some German idealists, especially Fichte, this approach is traceable up to several twentieth-century phenomenological and analytic philosophers (where perhaps the most important role belonged to Hector-Neri Castañeda with his 196os studies). ${ }^{24}$ Nevertheless, there is a striking difference between these philosophers and our patristic approach. According to the former, the non-objectal "I" is always something belonging to this world, even though not to its material segment. When they said that such "I" "is", they have had in mind "is" in a consistent way. This "is" does not imply "is not". According

22 This kind of inconsistent identity (between the human and the divine) is to be treated within the context of the doctrines of deification and Incarnation. To my opinion, it implies the paraconsistent logic; see B. Lourié, "Theodore the Studite's Christology against Its Logical Background," Studia Humana, 8 (2019), pp. 99-113.

23 This problem does not arise, of course, in the anthropologies following, in one or other way, the Cartesian body-soul (or mind) dualism, where the existence of a thinking subject is taken for granted and where it could be always addressed as an object. Cf., for the modern most prominent apology of such dualism, D.J. Chalmers, The Conscious Mind: In Search of a Fundamental Theory (Philosophy of Mind Series), Oxford, 1996; for criticisms, see esp. J.R. Searle including exchanges with D.C. Dennett and D.J. Chalmers, The Mystery of Consciousness, New York, 1997, and K. Frankish, "The Anti-Zombie Argument," Philosophical Quarterly, 57 (2007), pp. 65o-666.

24 For a survey and a discussion, see Manfred Frank, "Non-objectal Subjectivity," Journal of Consciousness Studies, 14 (2007), pp. 152-173. 
to the patristic approach, however, this "I" is nonexistent as any thing or any thought of this world, whereas does exist as a subject. Its mode of existence is therefore inconsistent.

On the opposite side of the spectrum of modern philosophers, there are those who deny the existence of such "I". According to this view (quite widespread today $)^{25}$, the word "I" has no reference at all, its apparent referent being "the (deeply rooted) grammatical illusion of a subject" (Elizabeth Anscombe). ${ }^{26}$

Wittgenstein stands alone, among the modern philosophers, with his quite peculiar idea of subjectivity. It is often misinterpreted by those commentators who take out of context his saying Das denkende, vorstellende, Subjekt gibt es nicht "There is no such thing as the subject that thinks or entertains ideas" (Tractatus, 5.631$)^{27}$ and, therefore, rank him in the "anti-referentialist" camp. ${ }^{28}$ Nevertheless, even those commentators who interpreted Wittgenstein correctly and even his close disciples or followers - such as David Pears and Elizabeth Anscombe - have never followed him in this matter.

25 Cf., as a general introduction, M. De Gaynesford, I: the Meaning of the First-Person Term, Oxford, 2006.

26 G.E.M. Anscombe, "The First Person" [lecture delivered in 1974], in: eadem, The Collected Philosophical Papers of G.E.M. Anscombe. Vol. 2: Metaphysics and the Philosophy of Mind, Oxford, 1981, pp. 21-36, at p. 36. Among the most influential anti-referentialists, one can recall Michel Foucault and Giorgio Agamben; cf. G. Agamben, Remnants of Auschwitz. The Witness and the Archive. Tr. by D. Heller-Roazen. New York, 1999, pp. 137-146.

L. Wittgenstein, Tractatus logico-philosophicus. The German text of Ludwig Wittgenstein's Logisch-philosophische Abhandlung with a new Translation by D.F. Pears \& B.F. McGuinness. (International Library of Philosophy and Scientific Method), London-New York, 1961, pp. 116/117 (txt/tr.).

28 Cf. De Gaynesford, I: the Meaning, p. 18; author's own summary of Wittgenstein's view (ibid.) is not quite correct either: "In brief: I may or may not refer. If it does refer, it is unclear what it refers to, through certainly not to a person." We will see that Wittgenstein was quite definitive in this matter. In my understanding of subjectivity in Wittgenstein, I am mostly indebted to Hans Sluga; cf. H. Sluga, "Subjectivity in the Tractatus," Synthese, 56 (1983), pp. 123-139; idem, "Whose House is That?' Wittgenstein on the self," in: The Cambridge Companion to Wittgenstein, eds. H. Sluga and D.G. Stern. Cambridge, 1996, pp. 320353 [not in the second edition of this Companion, 2018]. In fact, Wittgenstein later (in the Blue Book, 1933-1934) rejected referentialism in the very precise sense that it implies "an object co-existing with the sign" (L. Wittgenstein, Preliminary Studies for the "Philosophical Investigations" Generally known as the Blue and the Brown Books, Oxford, 1969, p.6; cf. p. 1; cf. also Sluga, "Whose House is That?", pp. 331-332), whereas "I" is not an object. Nikolas Loudovikos, who has the merit to be the first to compare Wittgenstein with patristic thought, incorrectly understands Wittgenstein in the Tractatus as a solipsist: cf. Loudovikos, " $\Delta t-\varepsilon v v o \eta \mu \alpha \dot{\tau} \omega \sigma \iota \varsigma$, " p. 161 (apparently, without taking into account the real dimension of the problem and the relevant studies of specialists in Wittgenstein). For Loudovikos, the Wittgensteinian "metaphysical I" seems to be a nothing, whereas the "I" as the subject of free will in Maximus seems to be a something. 
Wittgenstein's own idea has been shaped in repelling two extremities, both formulated by Bertrand Russell: Russell's 1913 view (that the ego is known by description and never by acquaintance) and his previous 1912 view (the exactly opposite theory rejected by Russell himself in 1913). ${ }^{29}$ Wittgenstein rejected both. Instead, he proposed a new understanding of the subject.

The metaphysical subject (ein metaphysisches Subjekt) is compared to the eye which sees the world but remains unseen by itself, being not a part of its own visual field (Tractatus, 5.633). The subject does not belong to the world but is the boundary/limit of the world - in the same manner as the eye does not belong to the visual field: Das Subjekt gehört nicht zur Welt, sondern es ist eine Grenze der Welt "The subject does not belong to the world: rather, it is a limit of the world" (Tractatus, 5.632). ${ }^{30}$ This is the explanation of Wittgenstein's statement in 5.631 that there is no such thing as the subject. ${ }^{31}$

The core and the most non-trivial notion is here that of the limit (Grenze) of the world. ${ }^{32}$ Taking into account Wittgenstein's mathematical implication, I would prefer to translate Grenze as "boundary" (which would refer to the fitting term from topology, unlike "limit" with its connotation of the irrelevant term from mathematical analysis). ${ }^{33}$

The "philosophical self" is such boundary of the world that is not a part of the world. It has nothing to do with psychology ${ }^{34}$ but is purely metaphysical. "The philosophical self [or "I"], continued Wittgenstein, is not the human being, not the human body, or the human soul, with which psychology deals, but rather the metaphysical subject, the limit [boundary] of the world - not a part of it" (Tractatus, 5.641). ${ }^{35}$ Such is the context of Wittgenstein's most famous

29 D. Pears, The False Prison: Study of the Development of Wittgenstein's Philosophy, 2 vols., Oxford, 1987-1988, vol. 1, pp.16o-161. Cf. also David Pears, "Wittgenstein's Treatment of Solipsism in the Tractatus," Crítica. Revista Hispanoamericana de Filosofía, 6 (1972), pp. 5784 .

$30 \quad$ Wittgenstein, Tractatus, pp. 116/117 (txt/tr.).

31 Wittgenstein, Tractatus, pp. 116/117 (txt/tr.).

32 'It is not altogether easy to understand Wittgenstein's idea of 'the limit', wrote his disciple and a Catholic philosopher Elizabeth Anscombe, whose remarks on this topic are especially relevant: G.E.M. Anscombe, An Introduction to Wittgenstein's Tractatus. Second Edition, Revised. New York, 1963, p. 169.

33 The translation of Grenze as "limit" has been approved, in this context, by Wittgenstein himself. I dare to break the established tradition, because I would like to propose a more "mathematical" paraphrasing of his ideas.

34 The non-psychological and non-physical nature of the metaphysical subject has been expressed in the later (The Blue Book,) Wittgenstein's term "the geometrical eye" as distinct from "the physical eye": Wittgenstein, Blue and the Brown Books, pp. 63-64, 72. 
and most difficult (for positivist-oriented commentators) definition of the mutual relations between "I" and the world (Tractatus, 5.64): ${ }^{36}$

Hier sieht man, daß der Solipsismus, streng durchgeführt, mit dem reinen Realismus zusammenfällt. Das Ich des Solipsismus schrumpft zum ausdehnungslosen Punkt zusammen, und es bleibt die ihm koordinierte Realität.

Here it can be seen that solipsism, when its implications are followed out strictly, coincides with pure realism. The self of solipsism shrinks to a point without extension, and there remains the reality co-ordinated with it.

The dimensionless point of the subject does not belong to the world but the world is co-ordinated with it. Quite a few patristic authors would have undersigned this claim, so little fitting in the positivist worldview. ${ }^{37}$ The "point" here is not a mere geometrical fiction, as would think someone who trivialises the implied logic by Wittgenstein. ${ }^{38}$ On the contrary, as Anscombe aptly formulated, this Wittgensteinian "I" "refers to the centre of life, or the point from which everything is seen". ${ }^{39}$

The imagery of point in 5.64 has the same meaning as that of limit/boundary (Grenze) but resulted from the comparison of the metaphysical subject with an eye, whereas the imagery of boundary resulted from understanding

der die Psychologie handelt, sondern das metaphysische Subjekt, die Grenze - nicht ein Teil - der Welt.

36 Wittgenstein, Tractatus, pp. $116 / 117$ (txt/tr.).

37 However, the ontology implied by Wittgenstein was by no means patristic: in the early period, he identified this "I" with the "world soul" (Wittgenstein, Notebooks, pp. 49/49e, on 23.05.1915: Es gibt wirklich nur eine Weltseele, welche ich vorzüglich mein Seele nenne, und als welche allein ich das erfasse, was ich die Seelen anderer nenne "There really is only one world soul, which I for preference call my soul and as which alone I conceive what I call the souls of others"), in the later period the implied ontology has certainly changed but remained unspecified. Cf. Sluga, "Whose House is That?'” pp. 330-332.

38 Cf. a recent example of misunderstanding of 5.64: "The subject of representation to which the world reduces is a mere point of reference and solipsism collapses into realism" (E.M. Lange, "Wittgenstein on Solipsism," in: A Companion to Wittgenstein, eds. H.-J. Glock and J. Hyman. (Blackwell Companions to Philosophy, 63), Oxford, 2017, pp. 159-174, at p. 165). One can see that, in Wittgenstein, not the world but "the I/self of solipsism" becomes a point, and there is neither collapse of solipsism into realism nor vice versa, but both of them "coincide." Wittgenstein is radically rewritten by his modern commentator to make him fitting in with the classical logic. This is a case of trivialisation of a logical problem instead of its resolution which would require pointing out the logic implied here.

Anscombe, An Introduction to Wittgenstein's Tractatus, p. 168. 
the world as a limited whole; both point and boundary are, in Wittgenstein, dimensionless.

Normally, a boundary of something is a line and, therefore, it has one dimension (not width but length). The boundary of the world, however, is different: it is the boundary between the whole and all (let us recall that Die Welt ist alles, was der Fall ist $)^{40}$. This means to be a boundary of an open set - which is not a part of its own set.

Hans Sluga helpfully applied to this problem Wittgenstein's own wording: "The I has not been reduced to nothing, but it also does not have the status of an object in the world, of a something".41

Topologically speaking, Wittgenstein considers the boundary between the open set All and its pseudo-complement Nothing (also an open set, unlike the normal topological complement of an open set, which must be a closed set). The two must have a boundary between them but both sets do not include boundary. The boundary is therefore at once present and absent. Such boundary could be defined in a strict way using the modern logic that Wittgenstein did not have at his disposal, ${ }^{42}$ but it could be elucidated as well with an easily

40 "The world is all that is the case" (Tractatus, 1); cf. the following claims where Wittgenstein explained the notions of "all" and of what is out this "all": 1.11. Die Welt ist durch Tatsachen bestimmt und dadurch, daß es alle Tatsachen sind "The world is determined by the facts, and by their being all the facts"; 1.12. Denn, die Gesamtheit der Tatsachen bestimmt, was der Fall ist und auch, was alles nicht der Fall ist "For the totality of facts determines what is the case, and also whatever is not the case"; Wittgenstein, Tractatus, pp. 6/7 (txt/tr.).

$41 \quad$ Sluga, "'Whose House is That?," p. 328. Sluga paraphrased here Wittgenstein's characteristic of the sensation of pain: Sie ist kein Etwas, aber auch nicht ein Nichts! "It is not a something, but not a nothing either!" (L. Wittgenstein, Philosophische Untersuchungen / Philosophical Investigations. ed. G.E.M. Anscombe, R. Rhees, tr. G.E.M. Anscombe. Oxford, 1958 [repr. 1999], pp. 102/102e, § 304 (txt/tr.)).

42 Namely, this is the case of the paracomplete topological separation conformed to the Heyting algebra instead of the Boolean one. In the Heyting algebra, " $a$ AND non- $a$ " results into zero (like in the Boolean: the law of non-contradiction is respected) but " $a$ or non- $a$ " could be less than 1 (unlike the Boolean algebra: the law of excluded middle is broken, this is the so-called truth-value gap). The boundary between the two open sets which does not belong to any of them is the very middle the classical logic requires to be excluded. Wittgenstein's subject between All and Nothing and the patristic subject of the free will between the created and the uncreated occupy the same position of the middle that the classical logic would require to have excluded. Cf. Ch. Mortensen, Inconsistent Geometry (Studies in Logic, 27), London, 2010, pp. 7-8. Wittgenstein himself, however, did not realise that the logic he de facto followed is theoretically possible. Thus, in Tractatus, 5.5303 he wrote: Beiläufig gesprochen: Von zwei Dingen zu sagen, sie seien identisch, ist ein Unsinn, und von Einem zu sagen, es sei identisch mit sich selbst, sagt gar nichts "Roughly speaking, to say of two things that they are identical is nonsense, and to say of one thing that it is identical with itself is to say nothing at all" (Wittgenstein, Tractatus, pp. 104/105 (txt/tr.)) 
understandable example that inspired Wittgenstein himself. Namely, the notion of Present is also a boundary between two open sets, the Past and the Future, and is elusive, logically speaking, in the same manner as our metaphysical subject. Present does not belong to either Past or Future and resists to objectivation. ${ }^{43}$

Far from being a pure abstraction, the "I" of Wittgenstein is not a something in the sense that it is not something, but certainly is not a nothing (a mere illusion of a self).

For Wittgenstein himself, it was a mystical feeling: Die Anschauung der Welt sub specie aeterni ist ihre Anschauung als - begrenztes - Ganzes. Das Gefühl der Welt als begrenztes Ganzes ist das mystische "To view the world sub specie aeterni is to view it as a whole - a limited whole. Feeling the world as a limited whole - it is this that is mystical" (Tractatus, 6.45) ${ }^{44}$ Elizabeth Anscombe, whereas acknowledging that "[i]t is difficult to get rid of such a conception once one has it", was firm in objecting: "One may well want to do so; e.g. one may feel that it makes the 'I' too godlike".45 Indeed, a Catholic philosopher as she was would have had to reject her teacher's views in the field of theology. Nevertheless, regardless of theology properly, from a purely logical point of view, Wittgenstein made a step away from all modern conceptions of subjectivity toward mediaeval ones, but rather patristic than scholastic. No wonder: Rowan Williams has already pointed out a similar case in Wittgenstein's "Christology".46

- thus denying, respectively, both paraconsistent (implying identity of two different things) and paracomplete (implying non-identity of a thing with itself) logics.

Cf. Wittgenstein's thoughts (inspired by but not identical to those of Schopenhauer) on the Present as exempt from the time: Wenn man unter Ewigkeit nicht unendliche Zeitdauer, sondern Unzeitlichkeit versteht, dann lebt der ewig, der in der Gegenwart lebt "If we take eternity to mean not infinite temporal duration but timelessness, then eternal life belongs to those who live in the present (Tractatus, 6.4311); Wittgenstein, Tractatus, pp. 146/147 (txt/tr.). Cf. H. Sluga, "Time and History in Wittgenstein," in: The Cambridge Companion to Wittgenstein. Second edition. Ed. H. Sluga and D.G. Stern. Cambridge, 2018, pp. 417-44O, at pp. 424-425.

44 Wittgenstein, Tractatus, pp. 148/149 (txt/tr.).

45 Anscombe, An Introduction to Wittgenstein's Tractatus, p. 168-169. She quoted here, among others, an even more explicit note: Es gibt zwei Gottheiten: die Welt und mein unabhängiges Ich "There are two godheads: the world and my independent I" (Wittgenstein, Notebooks, pp. 74/74e, on 8.07.1916).

46 Cf. R. Williams, "Wittgenstein, Kierkegaard and Chalcedon," in: Wittgenstein, Religion and Ethics. New Perspectives from Philosophy and Theology, ed. M. Burley, New York, 2018, pp. 77-92. I do not mention here the often discussed topic of the so-called Wittgensteinian "apophaticism"; cf. Ludwig Wittgenstein between Analytic Philosophy and Apophaticism. Ed. S. Mitralexis. Cambridge, 2015 (with further bibliography). 
Perhaps the closest patristic parallel to Wittgenstein's subjectivity is this Evagrian definition of the monk (of course, referring to the internal/spiritual

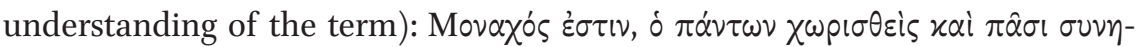

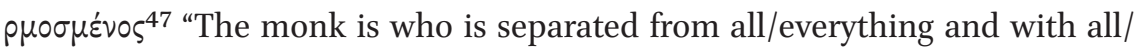
everything fitted together"; compare: Das Ich des Solipsismus schrumpft zum ausdehnungslosen Punkt zusammen, und es bleibt die ihm koordinierte Realität "The self of solipsism shrinks to a point without extension, and there remains the reality co-ordinated with it" (Tractatus 5.64).

\section{$8 \quad$ Conclusion}

Wittgenstein's understanding of subjectivity, however peculiar it may seem against the background of modern philosophy, was not so unique in a larger context of the early twentieth-century modernism in thinking and in arts. "Attention to the pure forms of logic, to the structures of mathematics and the clear lines of geometry provided these modernists with their clue to the spiritual. For all of them, the concern with form, far from being the expression of a flatfooted scientism, was meant to give access to a new kind of spirituality cleansed of all the historical associations of traditional religion," ${ }^{8}$ - "traditional" for the modern western world, of course, when the religion became rather a domain of emotions, moralism, or even sentimentality. This religious turn to "mathematics" from "emotions" was fitting in the sober asceticism of Byzantine Fathers with its appropriate anthropology.

From a formal (logical) point of view, the Wittgensteinian "I" that is not a something but not a nothing either, thus breaking the principle of excluded middle, is similar to the Byzantine ascetical "I" that is not a something in this world without being a nothing. Patristic approach to this "I" was, however, not static but dynamic. Being the subject of the free will, this "I" is always in change, to the better or to the worse, and there are means to make it better.

47 Evagrius, De oratione, 124; $P G$ 79, ${ }_{1193} \mathrm{C}$ (under the name of Nil of Sinai).

48 Sluga, "Time and History," p. 425; the author refers in particular to Mondrian, Malevich, and Kandinsky. His mention of Malevich is especially opportune, given that Malevich explained his artistic intuitions in written treatises. It would be interesting to compare with Malevich's idea of "nonobjectivity" of the world Wittgenstein's idea of world's Grenze. Cf. I. Hamilton Grant, "Suprematist Ontology and the Ultra Deep Field Problem: Operations of the Concept," in: Realism, Materialism, Art, ed. Ch. Cox, J. Jaskey, S. Malik. [New York], 2015, pp. 231-242. 